\title{
Geochemical characteristics of amphibolites in the Oki metamorphic rocks, Oki-Dogo Island, southwestern Japan: mixed occurrence of amphibolites with different geochemical affinity
}

\author{
Yoji ArakawA*, Tsugio KoutA** and Yasuhide KandA** \\ ${ }^{*}$ Geosphere Research Institute of Saitama University, \\ Saitama 338-8570, Japan \\ **Department of Geology, Faculty of Education, Saitama \\ University, Saitama 338-8570, Japan
}

\begin{abstract}
Geochemical analyses were performed on amphibolites in the Oki metamorphic rocks in Oki-Dogo Island, southwestern Japan. The amphibolites occur as layers or boulders in the pelitic and psammitic gneisses. Major and trace element characteristics suggest tholeiitic or alkaline chemical affinities and are divided into two groups (Group I and II). Group I amphibolites occurring as layers are characterized by low $\mathrm{SiO}_{2}$ (43.5- 46.6\%) and high $\mathrm{TiO}_{2}(>2.6 \%)$ and $\mathrm{P}_{2} \mathrm{O}_{5}(>0.5 \%)$, whereas Group II amphibolites by high $\mathrm{SiO}_{2}(46$. 5-47.6\%) and low $\mathrm{TiO}_{2}(<1.6 \%)$ and $\mathrm{P}_{2} \mathrm{O}_{5}(<0.2 \%)$. Relative enrichment of incompatible elements and their high ratios (such as $\mathrm{Zr} / \mathrm{Y}, \mathrm{Ti} / \mathrm{Y}, \mathrm{Ta} / \mathrm{Yb}$ ), and light rare-earth element (LREE) enriched patterns for Group I samples signify that the protoliths of Group I amphibolites correspond to within-plate basalt. In contrast, Group II amphibolites, marked by low contents of incompatible elements and nearly flat REE patterns, are further classified into three sub-groups (IIa, IIb and IIc). Group IIa and IIb amphibolites occur as boulders and the IIc as a layer in the psammitic gneissses. Group IIa and IIc amphibolites resemble tholeiitic basalt in oceanic island-arc tectonic setting, whilst the IIb amphibolite boulder represents chemical similarity to the E-type MORB. With exception of boulder-like amphibolites, the predominance of the Group I amphibolites suggests that the protolith formation of amphibolites (and clastic sedimentation) occurred in an intracontinental tectonic setting.
\end{abstract}

\section{Introduction}

The Oki belt forms one of the northernmost geotectonic units of Southwest Japan and comprises mainly of high grade metamorphic rocks and granites. The exposures are limited to the northeastern part of the Oki-Dogo Island (Fig. 1). Detailed geological and petrological investigations have been carried out on the metamorphic rocks of the Oki-Dogo Island (e.g., Ohta, 1963; Hoshino, 1979a and b). The main constituents of the metamorphic rocks are paragneiss, amphibolite and subordinate calcareous gneiss. Hoshino (1979a and b)

\footnotetext{
Y. Arakawa, yaraka@ post.saitama-u.ac.jp Corresponding author

T. Kouta

Y. Kanda
}

revealed that the rocks of the Oki belt underwent regional metamorphism of amphibolite facies, with granulite facies in part. Chronological works have shown that $\mathrm{K}-\mathrm{Ar}, \mathrm{Rb}-\mathrm{Sr}$ and $\mathrm{Sm}-\mathrm{Nd}$ mineral ages range from 165 to $187 \mathrm{Ma}$ (Shibata and Nozawa, 1966; Hayase and Ishizaka, 1967; Yamashita and Yanagi, 1994; Tanaka and Hoshino, 1987). Dallmeyer and Takasu (1998) reported ${ }^{40} \mathrm{Ar} /{ }^{39} \mathrm{Ar}$ mineral ages for the metamorphic rocks and discussed the cooling history of the Oki belt.

The metamorphic rocks of the Oki-Dogo Island have long been regarded as a western continuation of the Hida belt, both comprising high grade metamorphic rocks probably of Precambrian age and Mesozoic granites (e.g., Miyashiro, 1961; Ohta, 1963). However, recent chronological and geotectonic studies have made some revisions to the idea. For chronological works, 


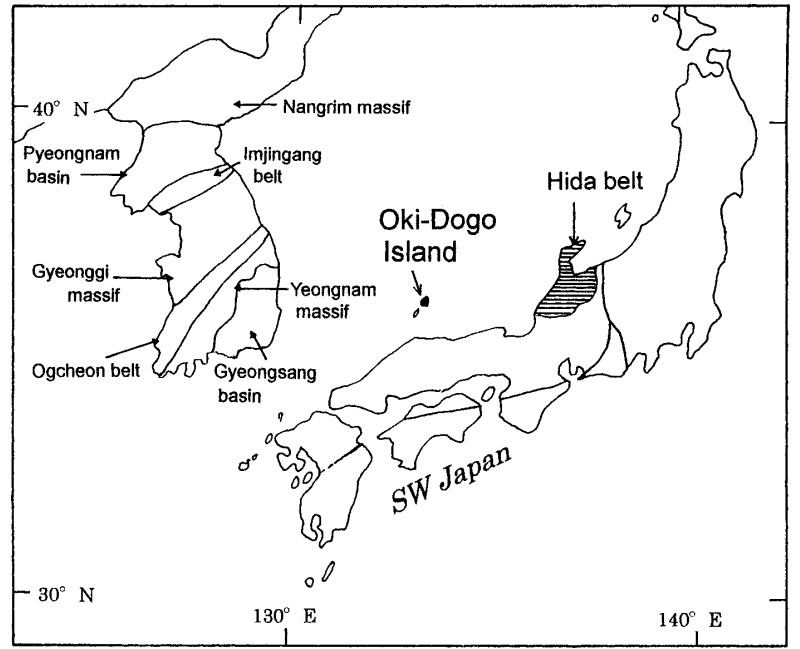

Figure 1. Geological framework of the Southwest Japan and Korean Peninsula, and the location of the Oki-Dogo Island. Tectonic division of the Korean Peninsula is from Lee et al. (1998).

Suzuki and Adachi (1994) has carried out a CHIME (chemical $\mathrm{Th}-\mathrm{U}$-total $\mathrm{Pb}$ isochron) age determination of monazite and zircon grains within the paragneisses of the Oki-Dogo Island and proposed a model that the protolith ages of the metamorphic rocks of the Oki belt are Carboniferous-Permian and later experienced a metamorphic event at ca. $250 \mathrm{Ma}$. They also showed that the zircon grains and monazite cores with Precambrian ages (up to $3000 \mathrm{Ma}$ ) may be detritals from the Precambrian basement as the provenances. Similar conclusion was reached by Yamashita and Yanagi (1994) using $\mathrm{U}-\mathrm{Pb}$ zircon chronology of pelitic gneisses. On the other hand, based on the differences in protolith lithology and Paleozoic faunal provinces in the surrounding regions Isozaki (1997) insisted that the Oki and Hida belts may have primarily formed and evolved in different continental margin (Oki belt in the Yangtze craton and the Hida belt in the Sino-Korean craton).

In spite of these studies, investigations have been sparse on the geochemistry of the metamorphic rocks, particularly for amphibolites which are probably of igneous origin, and which provide important information on the formation and development of the Oki belt. In this study we investigate geochemical characteristics of the amphibolites and discuss protolith chemistry, types of magmatism and tectonic implications.

\section{Geological outline, occurrence and petrography}

The Oki metamorphic rocks form a dome structure and are intruded by leucocratic granites and some dikes (Fig. 2). They are covered by Cenozoic sedimentary and volcanic rocks. The metamorphic rocks are dominantly composed of pelitic and psammitic gneisses, with minor amphibolite and calcareous gneiss. Some of them show migmatitic appearance. Amphibolites are mostly intercalated within the psammitic and pelitic gneiss layers, as a concordant layer (or sill-like body). Thinner amphibolite layers are sometimes variously deformed into an aggregate of lenticular blocks (Hoshino, 1979a). Some amphibolites without strong deformed structure occur as small boulders within the psammitic gneiss layer (Fig. 3). Leucocratic granites intruding the metamorphic rocks are divided into the older (undefined age) and younger (Miocene) granites (Tainosho et al., 1991).

Pelitic gneisses are medium- to coarse-grained and are composed mainly of biotite, plagioclase, quartz, $\mathrm{K}-$ feldspar, sillimanite with subordinate graphite, apatite, ilmenite, zircon and sphene. Psammitic gneisses are generally foliated and sometimes represent migmatitic appearance. Their main minerals are plagioclase, quartz, $\mathrm{K}$-feldspar, garnet and muscovite, with small amounts of apatite, graphite, zircon, sphene, monazite and ilmenite.

Amphibolite layers are generally 1 to $30 \mathrm{~m}$ in thickness. Their mineral assemblage is divided into two groups: 1) plagioclase-hornblende-clinopyroxeneorthopyroxene-quartz-ilmenite-pyrrhotite (-magnetite); 2) plagioclase-hornblende-quartz-ilmenite (-clinopyroxene-magnetite) (Hoshino, 1979a). The peak metamorphic temperature of the Oki metamorphic rocks is estimated to be ca. $800^{\circ} \mathrm{C}$ (Hoshino, 1979a; Tsunogae et al., 1995). In some amphibolites, retrogressive and alteration effects are observed with mantling of cummingtonite and actinolite around pyroxenes and hornblende, and partial replacement of chlorite to pyroxenes and hornblende (Hoshino, 1979a).

\section{Samples and analytical procedures}

Amphibolites in locations A, B and C (Fig. 2) have main mineral assemblage of plagioclase-hornblendeclinopyroxene-quartz, and those in locations $\mathrm{D}$ and $\mathrm{E}$ of plagioclase-hornblende-quartz. In location F (Fig. 2) the amphibolites present an assemblage of plagioclasehornblende-clinopyroxene-orthopyroxene-quartz (Fig. 2).

Least-altered amphibolite samples were selected for chemical analysis by careful checking of thin section under microscope. One altered amphibolite sample $(31-08 \mathrm{~B})$ is also used for chemical analysis. This is for comparison of element mobilization during secondary alteration with the least-altered samples. Major ele- 

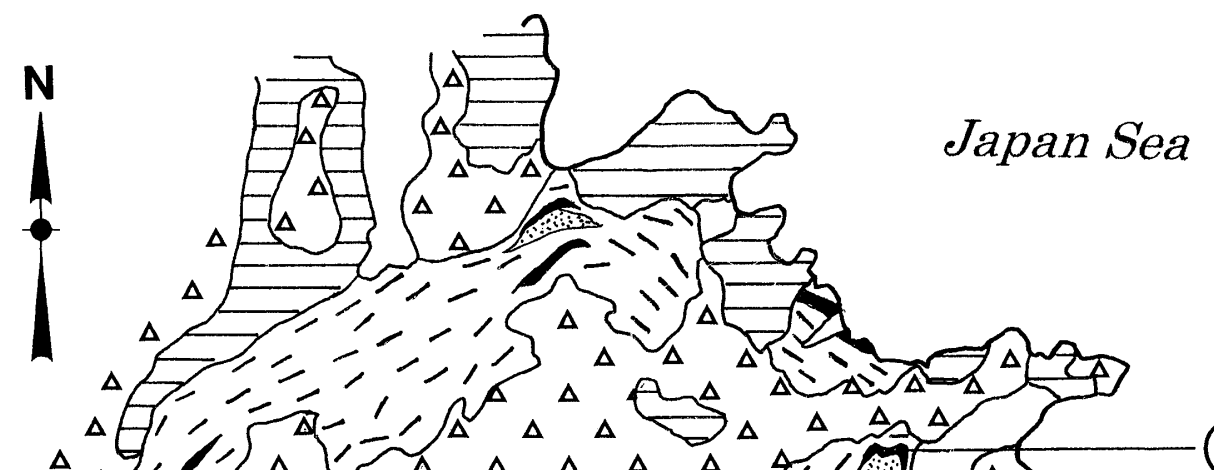

$\rightarrow \Delta, 1,{ }_{\Delta} \Delta \Delta \Delta \Delta \Delta \Delta \Delta \Delta$

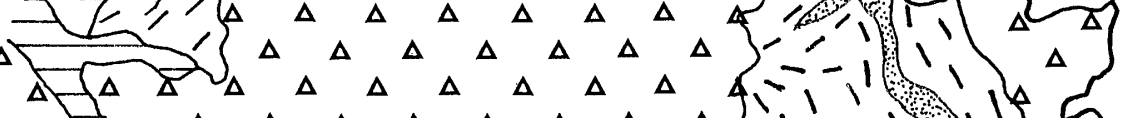

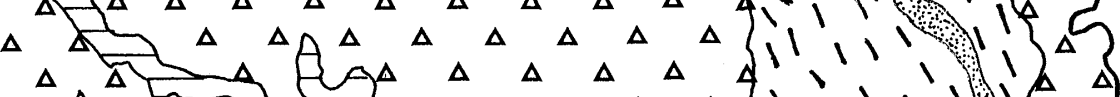

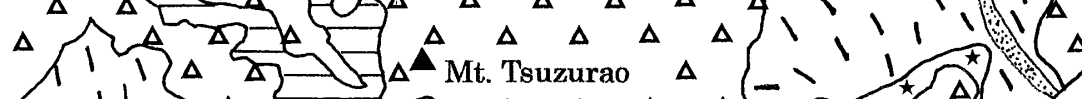

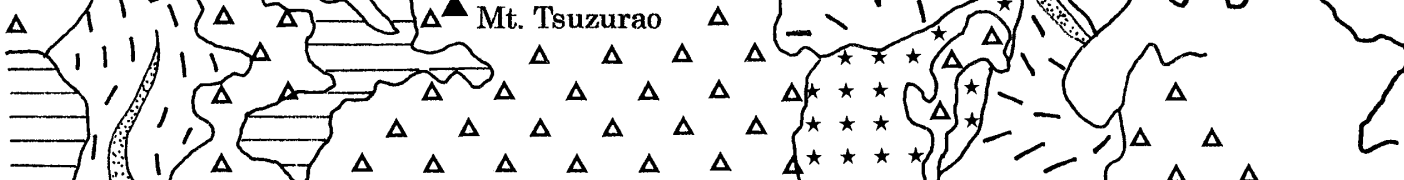

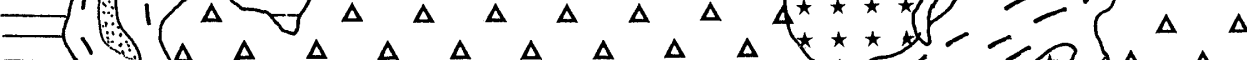

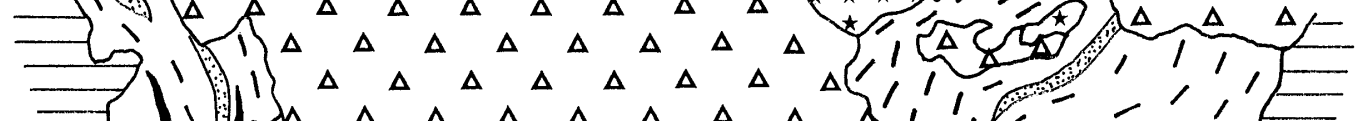

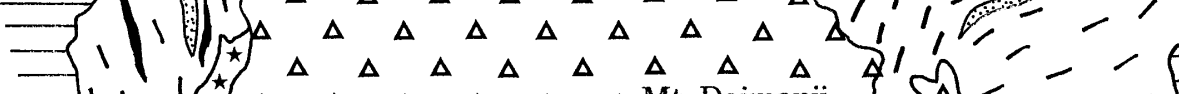
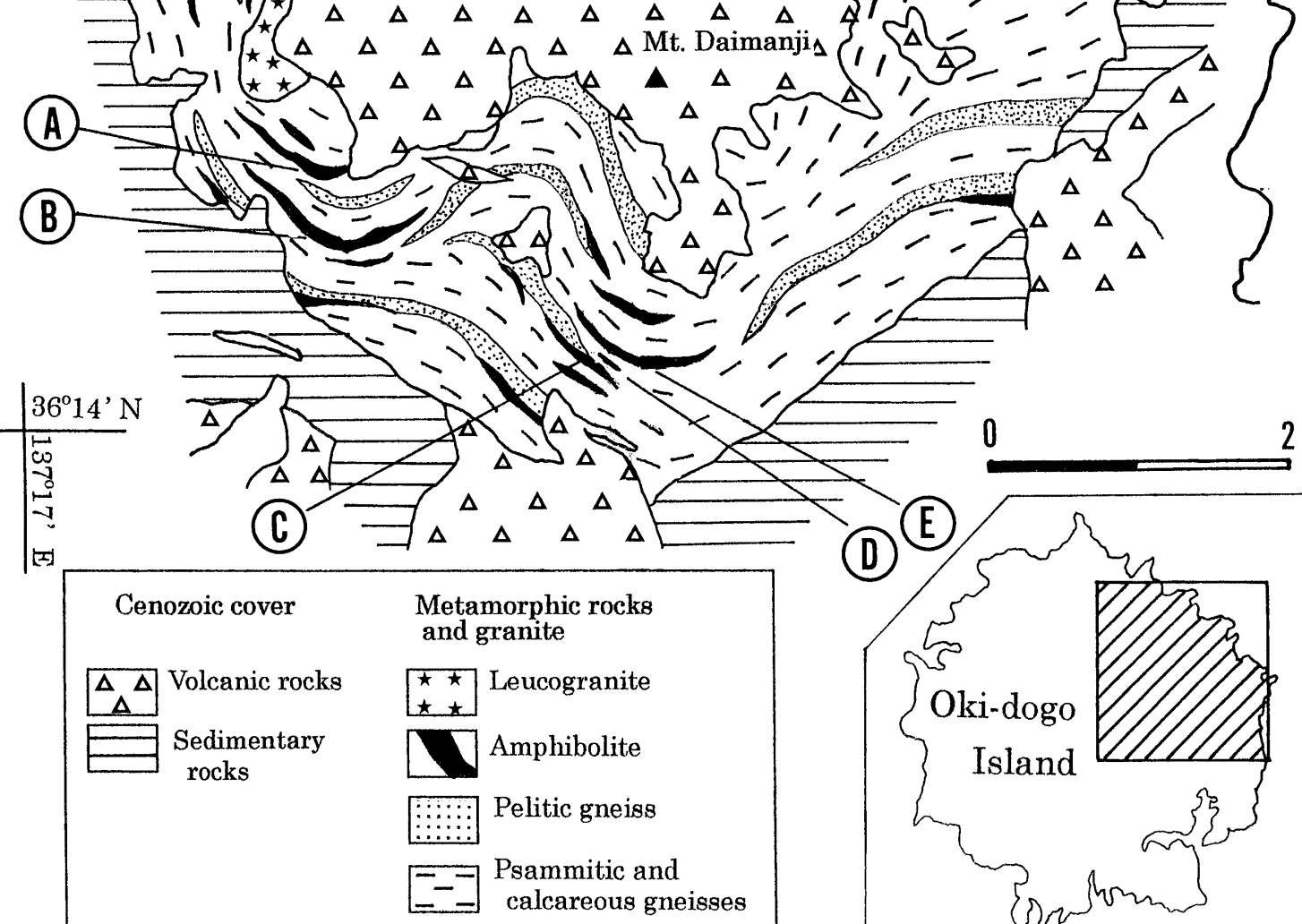

$2 \mathrm{~km}$

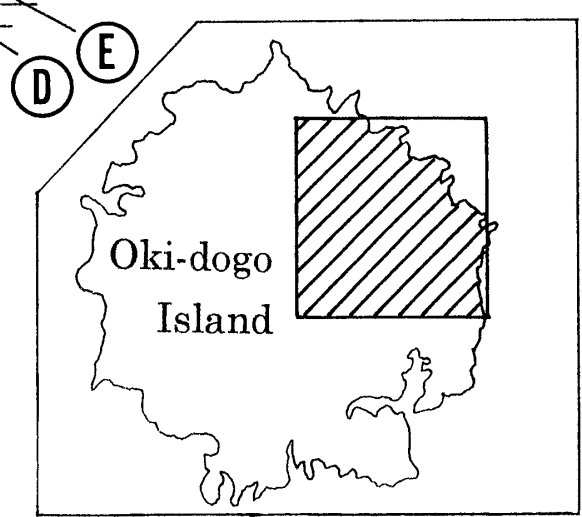

Figure 2. Geologic map of the northeastern part of the Oki-Dogo Island and sample localities (modified from Hoshino, 1979a and Suzuki and Adachi, 1994). 

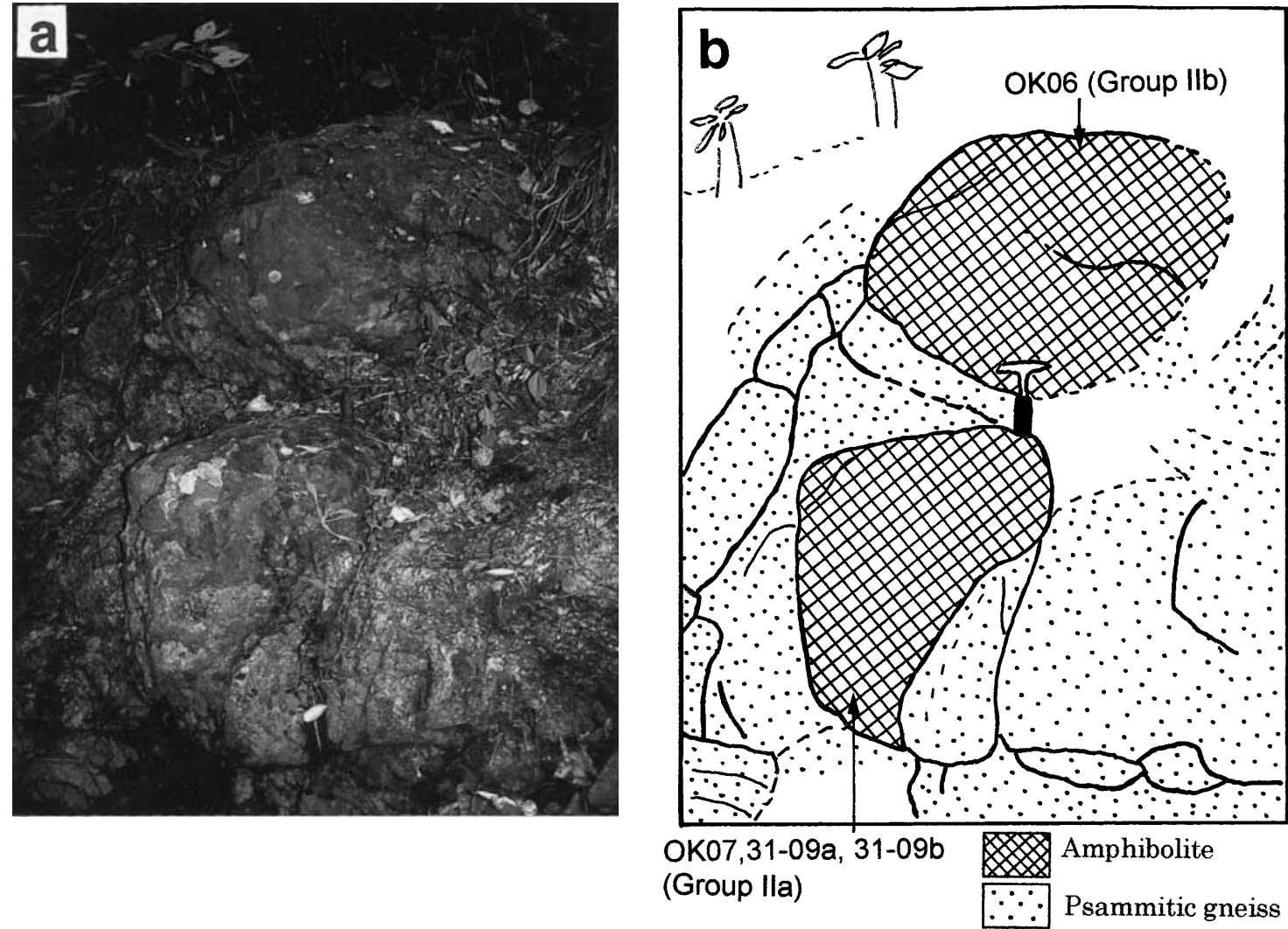

Figure 3. Photograph and sketch of the outcrop of amphibolites in location D.

ment and some trace element concentrations were measured using an X-ray fluorescence (XRF) spectrometer (Philips 2400) at Saitama University. Rare-earth element (REE) and $\mathrm{Hf}, \mathrm{Ta}, \mathrm{Nb}, \mathrm{U}$ and Th concentrations were determined by ICP-MS at Activation Laboratories Ltd., Canada.

\section{Results and discussion}

\section{Major and trace element geochemistry}

Major and trace element concentrations of amphibolites are listed in Table 1. Some major and trace element variation diagrams are presented in Figure 4. Analyzed amphibolites mostly exhibit a limited variation in element concentrations: $43.5-47.6 \%$ for $\mathrm{SiO}_{2}$ and 5.4-6.2\% for $\mathrm{MgO}$ except one altered sample (31-08B) (Fig. 4a). $\mathrm{Fe}_{2} \mathrm{O}_{3}(\mathrm{t})$ content is high (16.1-18.5\%) for all samples, and this may be related to the relative high amounts of ilmenite and magnetite in the samples. Alkaline element contents give slight variations: $1.2-2.5 \%$ for $\mathrm{Na}_{2} \mathrm{O}$ and $0.7-1.6 \%$ for $\mathrm{K}_{2} \mathrm{O}$. In contrast to these limited variations, $\mathrm{TiO}_{2}$ and $\mathrm{P}_{2} \mathrm{O}_{5}$ contents yield large variations among the samples analyzed (Fig. $4 \mathrm{~b}, \mathrm{c}$ ). Based on $\mathrm{TiO}_{2}$ and $\mathrm{P}_{2} \mathrm{O}_{5}$ contents they are classified into two groups (Group I and Group II). Group I amphibolites are characterized by low $\mathrm{SiO}_{2}(43.5-46.6 \%)$ and high $\mathrm{TiO}_{2}$ (2.6-5.2\% and $\mathrm{P}_{2} \mathrm{O}_{5}(0.5-1.2 \%)$, while the Group II amphibolites relatively high $\mathrm{SiO}_{2}$ (46.5-47.6\%), and low $\mathrm{TiO}_{2}(1.2-1.6 \%)$ and $\mathrm{P}_{2} \mathrm{O}_{5}(0.1-0.2 \%)$ (Fig. $4 \mathrm{~b}$ and c). $\mathrm{Mg}$ values $(\mathrm{Mg} \#)$ are concentrated in a narrow range: 42-47 for Group I and 43-48 for Group II (Table 1). Group I amphibolites generally show a layered (or silllike) occurrence within the psammitic and pelitic gneiss layers. Group II amphibolites occur as a layer (location $\mathrm{E}$ in Fig. 2) or a boulder (location D) in the gneiss layers. Figure 3 shows a photograph and sketch of the boulder-like amphibolites (Group II) from location D. Hoshino (1979a) pointed out that the amphibolites with high $\mathrm{SiO}_{2}$ content contain orthopyroxene. However, in this study the collected Group II amphibolites with relatively high $\mathrm{SiO}_{2}$ do not contain orthopyroxene.

On the $\mathrm{TiO}_{2}$ versus $\mathrm{Zr} /\left(\mathrm{P}_{2} \mathrm{O}_{5} \times 10000\right)$ and $\mathrm{Nb} / \mathrm{Y}$ versus $\mathrm{Zr} /\left(\mathrm{P}_{2} \mathrm{O}_{5} \times 10000\right)$ diagrams (Winchester and Floyd, 1977), Group I amphibolites fall in the field of alkaline to tholeiitic basalt, whereas Group II amphibolites in that of tholeiitic basalt (Fig. 4d, e). For compatible trace elements, $\mathrm{Cr}$ and $\mathrm{Ni}$ contents for the amphibolites of both groups are typically high with wide scatter: 78-605 ppm and 45-305 ppm, respectively. 

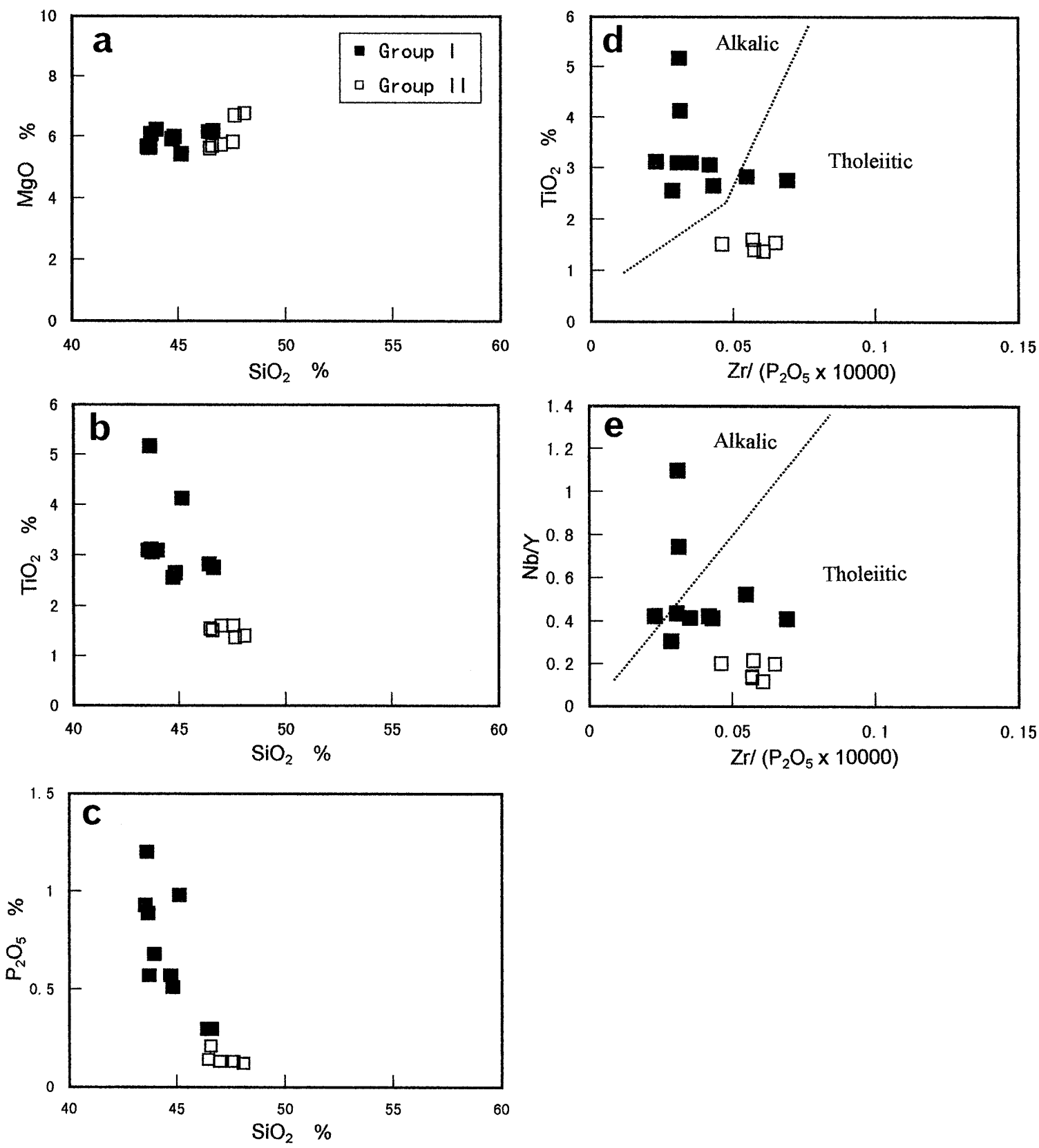

Figure 4. Selected major and trace element variation diagrams for amphibolites in the Oki belt.

These high contents of $\mathrm{Cr}$ and $\mathrm{Ni}$ indicate that the amphibolites are correlative to the ortho-amphibolite of Engel and Engel (1962), suggesting their igneous origin. Because their original igneous textures are mostly changed by metamorphism and deformation, we are not able to discriminate the original rocks of the amphibolites (such as meta-gabbro or meta-basalt).

Chondrite-normalized REE patterns for the amphibolites are given in Figure 5. Group I samples display moderately fractionated patterns with LREE enrichment $\left(\mathrm{La} / \mathrm{Yb}_{\mathrm{N}}\right.$ of 3.1-13.4). These patterns are clearly different from those of ocean floor basalt
(MORB). Absence of significant Eu anomaly implies that the plagioclase fractionation was not important in their magma genesis. On the other hand, Group II amphibolites are further classified into three sub-groups: IIa IIb and IIc. Group IIa and IIb samples are collected from different amphibolite boulders in a same outcrop (Fig. 3). The IIa samples have $\mathrm{La} / \mathrm{Yb}_{\mathrm{N}}$ of 1.42.8, whereas one IIb sample (OK06) shows slight HREE enrichment pattern $\left(\mathrm{La} / \mathrm{Yb}_{\mathrm{N}}=0.9\right)$. Two Group IIc samples are collected from a same layered amphibolite in location E (Fig. 2). One sample (OK04) is less altered, whereas the other sample (31-08B) is slightly 
Table 1. Bulk chemical compositions of

\begin{tabular}{|c|c|c|c|c|c|c|c|c|}
\hline \multirow{3}{*}{$\begin{array}{l}\text { Sample no. } \\
\text { Locality }\end{array}$} & \multicolumn{8}{|c|}{ Group I } \\
\hline & $\mathrm{KH} 01$ & KH02 & OK10 & OK11 & OK21' & OK24 & OK25 & OK26 \\
\hline & $\mathrm{B}^{*}$ & $\mathrm{~B}$ & $\mathrm{C}$ & $\mathrm{C}$ & A & A & A & A \\
\hline $\mathrm{SiO}_{2}(\%)$ & 43.61 & 45.13 & 43.67 & 43.54 & 43.96 & 44.81 & 44.71 & 43.72 \\
\hline $\mathrm{TiO}_{2}$ & 5.17 & 4.13 & 3.12 & 3.10 & 3.10 & 2.65 & 2.56 & 3.06 \\
\hline $\mathrm{Al}_{2} \mathrm{O}_{3}$ & 13.73 & 14.34 & 13.40 & 13.40 & 13.51 & 14.35 & 13.72 & 13.58 \\
\hline $\mathrm{Fe}_{2} \mathrm{O}_{3} * *$ & 18.01 & 17.03 & 18.31 & 18.47 & 18.40 & 16.15 & 17.09 & 17.62 \\
\hline $\mathrm{MnO}$ & 0.34 & 0.30 & 0.28 & 0.28 & 0.31 & 0.22 & 0.23 & 0.25 \\
\hline $\mathrm{MgO}$ & 5.63 & 5.43 & 5.65 & 5.67 & 6.23 & 6.00 & 5.92 & 6.09 \\
\hline $\mathrm{CaO}$ & 7.31 & 8.38 & 9.09 & 9.14 & 9.55 & 9.46 & 9.38 & 9.44 \\
\hline $\mathrm{Na}_{2} \mathrm{O}$ & 1.74 & 1.83 & 2.18 & 2.25 & 2.46 & 2.17 & 2.41 & 2.48 \\
\hline $\mathrm{K}_{2} \mathrm{O}$ & 0.87 & 0.68 & 1.09 & 1.06 & 1.28 & 1.29 & 1.26 & 1.26 \\
\hline $\mathrm{P}_{2} \mathrm{O}_{5}$ & 1.20 & 0.98 & 0.89 & 0.93 & 0.68 & 0.51 & 0.57 & 0.57 \\
\hline LOI & 1.82 & 1.35 & 1.58 & 1.48 & 0.32 & 1.91 & 1.33 & 0.86 \\
\hline Total & 99.43 & 99.58 & 99.26 & 99.35 & 99.80 & 99.52 & 99.18 & 98.93 \\
\hline$\# \mathrm{Mg} * * *$ & 42.1 & 42.7 & 41.8 & 41.7 & 44.2 & 46.4 & 44.7 & 44.6 \\
\hline $\mathrm{V} \quad \mathrm{ppm}$ & 285 & 306 & 474 & 364 & 706 & 428 & 291 & 466 \\
\hline $\mathrm{Cr}$ & 78 & 132 & 170 & 208 & 312 & 157 & 140 & 605 \\
\hline $\mathrm{Ni}$ & 69 & 51 & 45 & 132 & 108 & 99 & 19 & 305 \\
\hline $\mathrm{Cu}$ & & & 78 & 72 & 63 & 55 & 50 & 57 \\
\hline $\mathrm{Zn}$ & 72 & 88 & 42 & 265 & 186 & 170 & 46 & 275 \\
\hline $\mathrm{Rb}$ & 28 & 15 & 31 & 27 & 65 & 37 & 21 & 25 \\
\hline $\mathrm{Ba}$ & 380 & 279 & 390 & 361 & 609 & 444 & 514 & 790 \\
\hline $\mathrm{Sr}$ & 306 & 283 & 262 & 260 & 353 & 269 & 281 & 256 \\
\hline $\mathrm{Nb}$ & 35.9 & 28.7 & 19.6 & 31.2 & 18.7 & 18.2 & 10.2 & 19.5 \\
\hline $\mathrm{Zr}$ & 370 & 305 & 202 & 325 & 210 & 211 & 160 & 237 \\
\hline$Y$ & 33 & 39 & 46 & 75 & 43 & 44 & 33 & 45 \\
\hline $\mathrm{Hf}$ & 8.4 & 7.1 & 4.9 & 6.2 & 5.1 & 4.1 & 3.9 & 4.0 \\
\hline $\mathrm{Ta}$ & 2.2 & 1.6 & 1.0 & 1.6 & 0.9 & 1.2 & 0.7 & 1.1 \\
\hline Th & 0.83 & 0.65 & 0.97 & 1.40 & 2.47 & 1.41 & 1.29 & 1.97 \\
\hline $\mathrm{U}$ & 0.64 & 0.50 & 0.24 & 0.87 & 0.66 & 0.76 & 0.32 & 1.05 \\
\hline $\mathrm{La} \quad \mathrm{ppm}$ & 32.95 & 28.28 & 45.16 & 55.30 & 40.00 & 31.20 & 33.11 & 35.00 \\
\hline $\mathrm{Ce}$ & 68.03 & 62.05 & 100.8 & 127.8 & 83.61 & 71.46 & 67.70 & 79.38 \\
\hline $\operatorname{Pr}$ & 9.36 & 9.27 & 14.00 & 18.30 & 11.27 & 9.84 & 9.03 & 10.80 \\
\hline $\mathrm{Nd}$ & 38.70 & 39.41 & 55.09 & 77.20 & 45.00 & 41.30 & 36.10 & 45.10 \\
\hline $\mathrm{Sm}$ & 7.41 & 7.97 & 10.40 & 15.07 & 8.72 & 8.42 & 6.94 & 8.73 \\
\hline $\mathrm{Eu}$ & 2.04 & 2.14 & 2.78 & 3.37 & 2.82 & 2.23 & 2.00 & 2.29 \\
\hline $\mathrm{Gd}$ & 6.70 & 7.48 & 9.26 & 14.24 & 8.00 & 8.03 & 6.33 & 7.89 \\
\hline $\mathrm{Tb}$ & 1.07 & 1.26 & 1.45 & 2.12 & 1.31 & 1.28 & 1.03 & 1.20 \\
\hline Dy & 5.30 & 6.31 & 7.24 & 12.62 & 6.86 & 7.71 & 5.31 & 7.33 \\
\hline Ho & 0.92 & 1.13 & 1.29 & 2.30 & 1.22 & 1.39 & 0.92 & 1.35 \\
\hline $\mathrm{Er}$ & 2.66 & 3.30 & 3.81 & 6.93 & 3.55 & 4.13 & 2.70 & 4.04 \\
\hline $\mathrm{Tm}$ & 0.36 & 0.45 & 0.52 & 0.94 & 0.47 & 0.54 & 0.36 & 0.53 \\
\hline $\mathrm{Yb}$ & 2.57 & 2.98 & 3.45 & 6.33 & 3.30 & 3.80 & 2.47 & 3.75 \\
\hline $\mathrm{Lu}$ & 0.45 & 0.49 & 0.57 & 0.10 & 0.55 & 0.59 & 0.41 & 0.59 \\
\hline
\end{tabular}

*Sample locality in Figure 2. ${ }^{* *}$ Total iron as $\mathrm{Fe}_{2} \mathrm{O}_{3}$. $\quad{ }^{* * *} \mathrm{Mg} \#=\mathrm{Mg} /\left(\mathrm{Mg}+\mathrm{Fe}^{2+}\right)$, assuming $\mathrm{Fe}_{2} \mathrm{O}_{3} /\left(\mathrm{FeO}^{*} \mathrm{Fe}_{2} \mathrm{O}_{3}\right)=0.15$.

altered with partial replacement of chlorite to pyroxene and hornblende, and sericite and other fine-grained minerals to plagioclase. However, relative enrichment of overall REE abundance for the altered sample (3108B) compared with those of less altered sample (OK04) may not be explained easily by an alteration effect. A negative $\mathrm{Eu}$ anomaly of the altered sample may have resulted from alteration of plagioclase, but their high $\mathrm{Al}$ and $\mathrm{Sr}$, and low LOI do not suggest the alteration of plagioclase. Low $\mathrm{CaO}$ content of 31-08B may be related to the alteration of clinopyroxene (Table 1).

The N-MORB normalized spidergrams for the amphibolites are shown in Figure 6. Group I samples show similar trace element abundances characterized by the enrichment of highly incompatible elements $(\mathrm{Rb}, \mathrm{Ba}$, $\mathrm{Th}$ and $\mathrm{K}$ ) and slight depletion of $\mathrm{Sr}, \mathrm{Yb}$ and $\mathrm{Lu}$. 
amphibolites in the Oki metamorphic rocks

\begin{tabular}{|c|c|c|c|c|c|c|c|c|}
\hline \multirow[b]{2}{*}{$\begin{array}{l}\text { Sample no. } \\
\text { Locality }\end{array}$} & \multicolumn{2}{|c|}{ Group I } & \multicolumn{3}{|c|}{ Group Ia } & \multirow{2}{*}{$\begin{array}{c}\text { Group Ilb } \\
\text { OK06 } \\
\text { D }\end{array}$} & \multicolumn{2}{|c|}{ Group IIc } \\
\hline & $\begin{array}{c}\text { OK34 } \\
\text { F }\end{array}$ & $\begin{array}{l}\text { OK37 } \\
\mathrm{F} \\
\end{array}$ & $\begin{array}{c}31-09 a \\
D \\
\end{array}$ & $\begin{array}{c}31-09 b \\
D\end{array}$ & $\begin{array}{l}\text { OK07 } \\
\mathrm{D}\end{array}$ & & $\begin{array}{c}\text { OK04 } \\
\mathrm{E} \\
\end{array}$ & $\begin{array}{c}31-08 B \\
E\end{array}$ \\
\hline $\mathrm{SiO}_{2}(\%)$ & 46.60 & 46.40 & 47.00 & 47.56 & 46.48 & 46.59 & 46.96 & 48.09 \\
\hline $\mathrm{TiO}_{2}$ & 2.76 & 2.83 & 1.60 & 1.60 & 1.54 & 1.51 & 1.19 & 1.40 \\
\hline $\mathrm{Al}_{2} \mathrm{O}_{3}$ & 13.26 & 13.14 & 12.94 & 13.06 & 12.84 & 13.15 & 13.45 & 15.01 \\
\hline $\mathrm{Fe}_{2} \mathrm{O}_{3} * *$ & 16.48 & 16.60 & 17.32 & 17.20 & 17.31 & 16.75 & 16.07 & 17.38 \\
\hline $\mathrm{MnO}$ & 0.22 & 0.21 & 0.23 & 0.24 & 0.23 & 0.22 & 0.21 & 0.19 \\
\hline $\mathrm{MgO}$ & 6.20 & 6.10 & 5.72 & 5.81 & 5.60 & 5.68 & 6.05 & 6.76 \\
\hline $\mathrm{CaO}$ & 9.33 & 9.30 & 9.49 & 9.36 & 9.46 & 8.42 & 8.80 & 5.49 \\
\hline $\mathrm{Na}_{2} \mathrm{O}$ & 1.78 & 1.95 & 1.24 & 1.23 & 1.76 & 2.12 & 2.02 & 1.79 \\
\hline $\mathrm{K}_{2} \mathrm{O}$ & 1.03 & 1.10 & 1.58 & 1.58 & 1.12 & 0.85 & 1.10 & 0.97 \\
\hline $\mathrm{P}_{2} \mathrm{O}_{5}$ & 0.28 & 0.30 & 0.13 & 0.13 & 0.14 & 0.21 & 0.12 & 0.12 \\
\hline LOI & 1.64 & 1.51 & 2.14 & 1.86 & 2.33 & 3.48 & 3.70 & 2.47 \\
\hline Total & 99.58 & 99.50 & 99.39 & 99.63 & 99.05 & 98.89 & 99.67 & 99.67 \\
\hline$\# \mathrm{Mg} * * *$ & 46.8 & 46.5 & 43.5 & 44.1 & 43.0 & 44.1 & 46.7 & 47.6 \\
\hline $\mathrm{V} \quad \mathrm{ppm}$ & 465 & 477 & 461 & 444 & 446 & 443 & 359 & 382 \\
\hline $\mathrm{Cr}$ & 197 & 189 & 118 & 134 & 143 & 128 & 146 & 151 \\
\hline $\mathrm{Ni}$ & 114 & 48 & 89 & 92 & 95 & 94 & 96 & 73 \\
\hline $\mathrm{Cu}$ & 46 & 44 & 28 & 27 & 25 & 25 & 47 & 24 \\
\hline $\mathrm{Zn}$ & 172 & 159 & 108 & 109 & 218 & 192 & 171 & 152 \\
\hline $\mathrm{Rb}$ & 57 & 59 & 37 & 42 & 29 & 15 & 30 & 37 \\
\hline $\mathrm{Ba}$ & 199 & 269 & 451 & 493 & 297 & 113 & 181 & 193 \\
\hline $\mathrm{Sr}$ & 253 & 260 & 183 & 206 & 159 & 135 & 115 & 181 \\
\hline $\mathrm{Nb}$ & 16.9 & 18.7 & 4.6 & 4.7 & 6.5 & 7.8 & 6.5 & 11.4 \\
\hline $\mathrm{Zr}$ & 191 & 208 & 73 & 74 & 90 & 95 & 78 & 69 \\
\hline$Y$ & 41 & 33 & 35 & 35 & 33 & 39 & 36 & 43 \\
\hline $\mathrm{Hf}$ & 3.8 & 4.2 & 2.1 & 2.1 & 2.1 & 2.3 & 2.0 & 2.1 \\
\hline $\mathrm{Ta}$ & 1.2 & 1.4 & 0.2 & 0.2 & 0.3 & 0.6 & 1.1 & 0.4 \\
\hline Th & 0.68 & 0.60 & 0.94 & 1.05 & 1.28 & 0.48 & 1.23 & 5.26 \\
\hline $\mathrm{U}$ & 0.41 & 0.26 & 0.43 & 0.50 & 0.60 & 0.43 & 1.14 & 1.28 \\
\hline La ppm & 15.31 & 15.73 & 7.83 & 8.50 & 7.17 & 5.48 & 12.30 & 24.65 \\
\hline $\mathrm{Ce}$ & 40.50 & 38.03 & 17.05 & 19.32 & 18.45 & 14.31 & 32.11 & 53.41 \\
\hline $\operatorname{Pr}$ & 6.75 & 6.00 & 2.30 & 2.44 & 2.77 & 2.35 & 4.26 & 64.09 \\
\hline $\mathrm{Nd}$ & 32.10 & 26.80 & 12.11 & 11.66 & 12.60 & 12.10 & 17.10 & 28.86 \\
\hline $\mathrm{Sm}$ & 7.95 & 6.80 & 3.66 & 3.83 & 3.60 & 3.76 & 3.98 & 7.27 \\
\hline $\mathrm{Eu}$ & 1.99 & 1.94 & 1.55 & 1.56 & 1.23 & 1.16 & 1.15 & 1.04 \\
\hline $\mathrm{Gd}$ & 7.90 & 6.36 & 5.56 & 4.92 & 4.27 & 4.67 & 4.44 & 7.29 \\
\hline $\mathrm{Tb}$ & 1.36 & 1.12 & 0.95 & 0.93 & 0.82 & 0.94 & 0.79 & 1.24 \\
\hline Dy & 7.52 & 5.70 & 5.09 & 5.06 & 5.40 & 6.22 & 5.35 & 6.89 \\
\hline Ho & 1.33 & 0.98 & 1.03 & 0.97 & 1.06 & 1.23 & 1.05 & 1.28 \\
\hline $\mathrm{Er}$ & 3.91 & 2.63 & 2.79 & 2.58 & 3.44 & 3.98 & 3.38 & 3.41 \\
\hline Tm & 0.49 & 0.35 & 0.48 & 0.47 & 0.45 & 0.56 & 0.47 & 0.60 \\
\hline $\mathrm{Yb}$ & 3.35 & 2.28 & 3.01 & 3.08 & 3.46 & 4.07 & 3.53 & 4.54 \\
\hline $\mathrm{Lu}$ & 0.50 & 0.37 & 0.45 & 0.48 & 0.58 & 0.68 & 0.62 & 0.66 \\
\hline
\end{tabular}

Distinct negative anomalies of $\mathrm{Ta}$ and $\mathrm{Nb}$, which are typical characteristics of subduction-related magmas (e.g., Saunders and Terney, 1979) or crustal contamination by mantle-derived magmas (e.g., Cox and Hawkesworth, 1985; Jahn et al., 1999), are not found except in two samples. Three Group IIa amphibolites present quite similar patterns with enrichment of $\mathrm{Rb}, \mathrm{Ba}$ and $\mathrm{K}$, and depletion of $\mathrm{Ta}$ and $\mathrm{Nb}$ (Fig. 6). Protoliths of these IIa samples may correlate to the subductionrelated volcanic rocks or the rocks affected by crustal contamination. Compared with the Group IIa, Group IIb sample (OK06) shows typical absence of negative anomalies of $\mathrm{Ta}$ and $\mathrm{Nb}$, and low contents of relatively mobile elements $(\mathrm{Rb}, \mathrm{Ba}$ and $\mathrm{K})$. The spidergram of less-altered Group IIc sample (OK04) resembles with those of the Group IIa. An altered sample (31-08B) possesses slight higher values in most of the elements than the OK04. This seems to be inconsistent with the element mobility during metamorphism and alteration. In some cases, various degrees of depletion in light rare- 

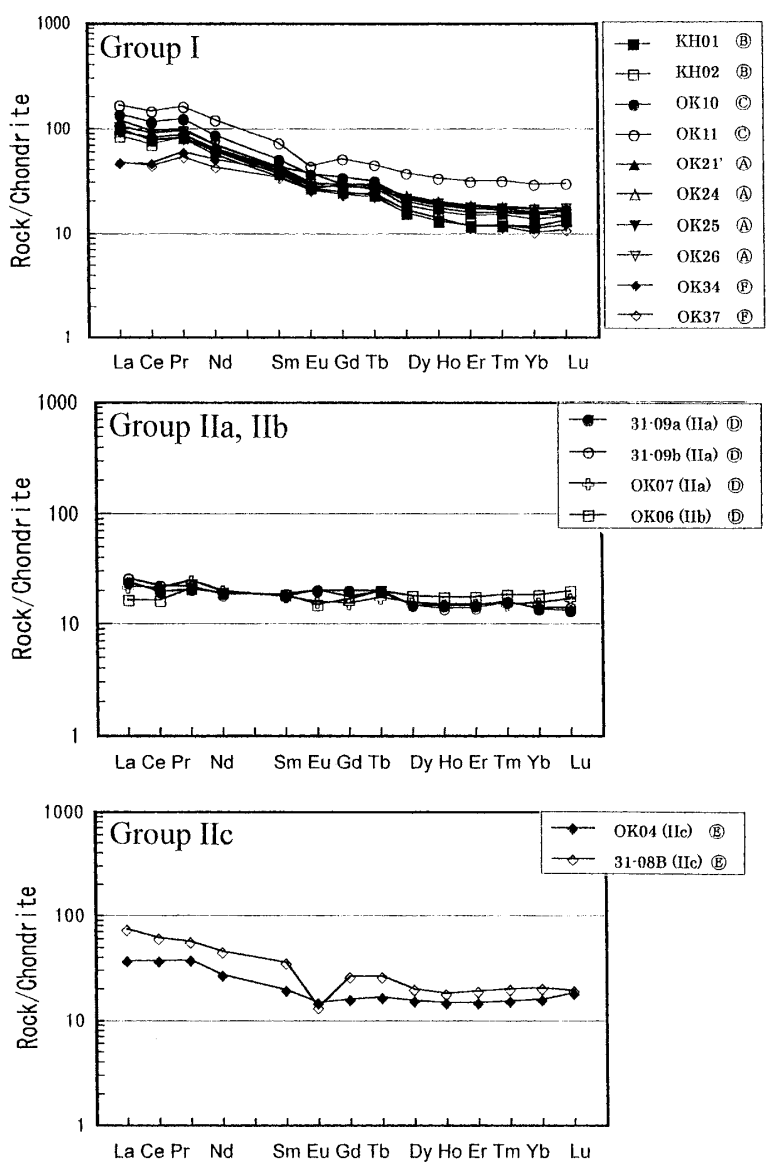

Figure 5. Chondrite-normalized rare-earth element (REE) patterns for different types of amphibolites. Group IIa and IIb samples are from different boulders at the same outcrop (Fig. 3). Symbols (A) ( $\sim$ ) show sample locations in Figure 2. OK04 (Group IIc) is less-altered and $31-08 \mathrm{~B}$ is slightly altered.

earth element (LREE) such as $\mathrm{La}$ and $\mathrm{Ce}$, and large-ion lithophile elements (LILE) are documented in the metamorphosed or altered igneous rocks, and are interpreted to be caused by fluid-rock interaction during metamorphism and secondary alteration (e.g., Jahn et al., 1996; Asaki and Yoshida, 1998). Except some elements, the overall differences in the patterns of spidergram and the REE between the less-altered and altered Group IIc samples may be attributed to the original heterogeneity in bulk chemical composition within the same layer.

\section{Tectonic setting}

Generally high field strength elements (HFSE) such as $\mathrm{Zr}, \mathrm{Nb}, \mathrm{Ta}, \mathrm{Y}, \mathrm{Hf}$ and $\mathrm{Ti}$ are considered to be immobile during metamorphism and secondary alteration compared with the alkaline elements such as $\mathrm{K}, \mathrm{Na}, \mathrm{Ba}$ and $\mathrm{Rb}$. So, using discrimination diagrams based on the HFSE
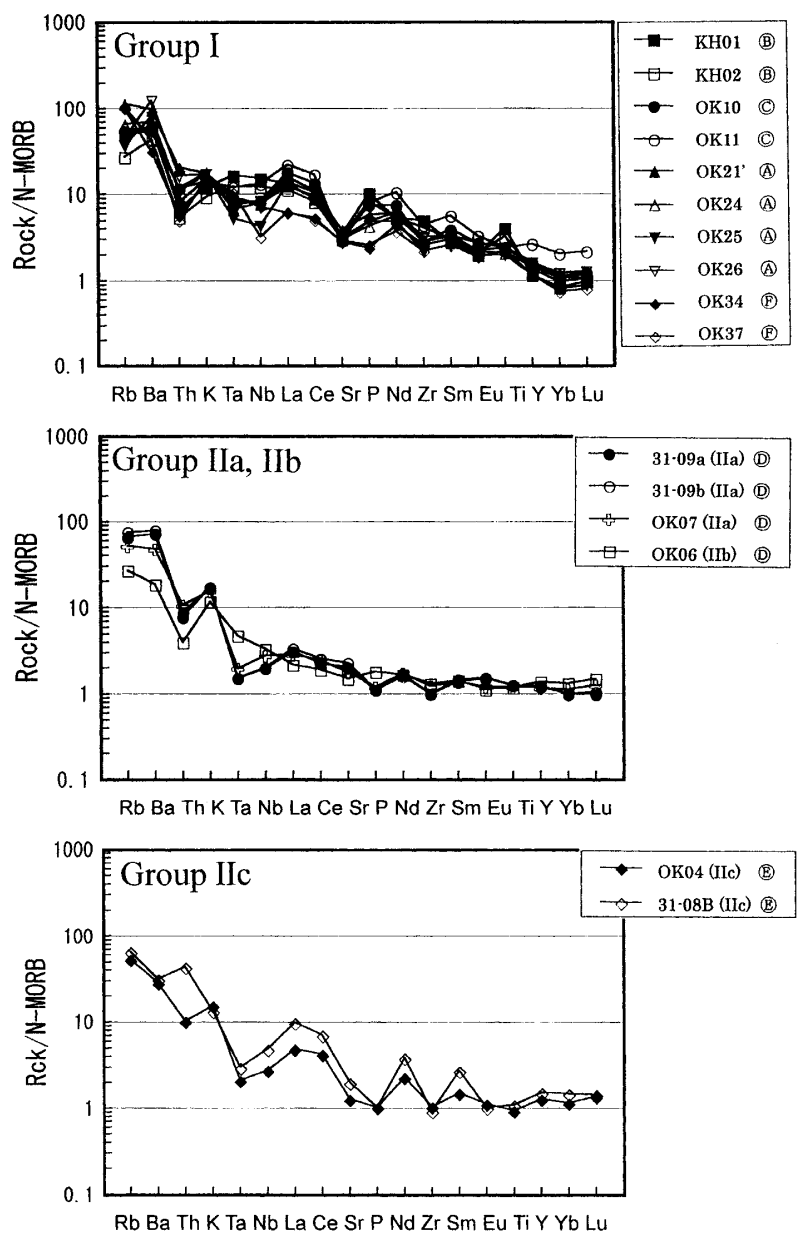

Figure 6. N-MORB normalized incompatible element patterns (spidergrams) for amphibolites in the Oki belt. Normalizing values are from Sun and McDonough (1989).

we can identify the reliable tectonic setting for the protoliths of the amphibolite. On the $\mathrm{Zr}-\mathrm{Zr} / \mathrm{Y}$ diagram (Fig. 7a), Group I amphibolites are plotted in within-plate basalt (WPB) field, whereas Group II amphibolites lie in the island-arc tholeiite (IAT) or midoceanic ridge basalt (MORB) field. Most of the Group I amphibolites are marked by high $\mathrm{Ti} / \mathrm{Y}$ and $\mathrm{Nb} / \mathrm{Y}$ and plot in the within-plate basalt field (Fig. 7b). On the other hand, Group II amphibolites show relatively low values of $\mathrm{Ti} / \mathrm{Y}$ and $\mathrm{Nb} / \mathrm{Y}$, and are limited within the volcanic arc basalt or MORB field (Fig. 7b). In the Th-Hf/3-Ta diagram (Wood et al., 1979), Group II samples are further classified into two different basalt types (Fig. 8). Group IIa and IIc samples are plotted in the volcanic arc basalt (VAB) field, while Group IIb sample (OK06) falls within the E-type MORB (EMORB) field. This is due to the difference in their Ta and Th contents, as seen in the spidergrams (Fig. 6). The REE and spidergram patterns except some alkaline 

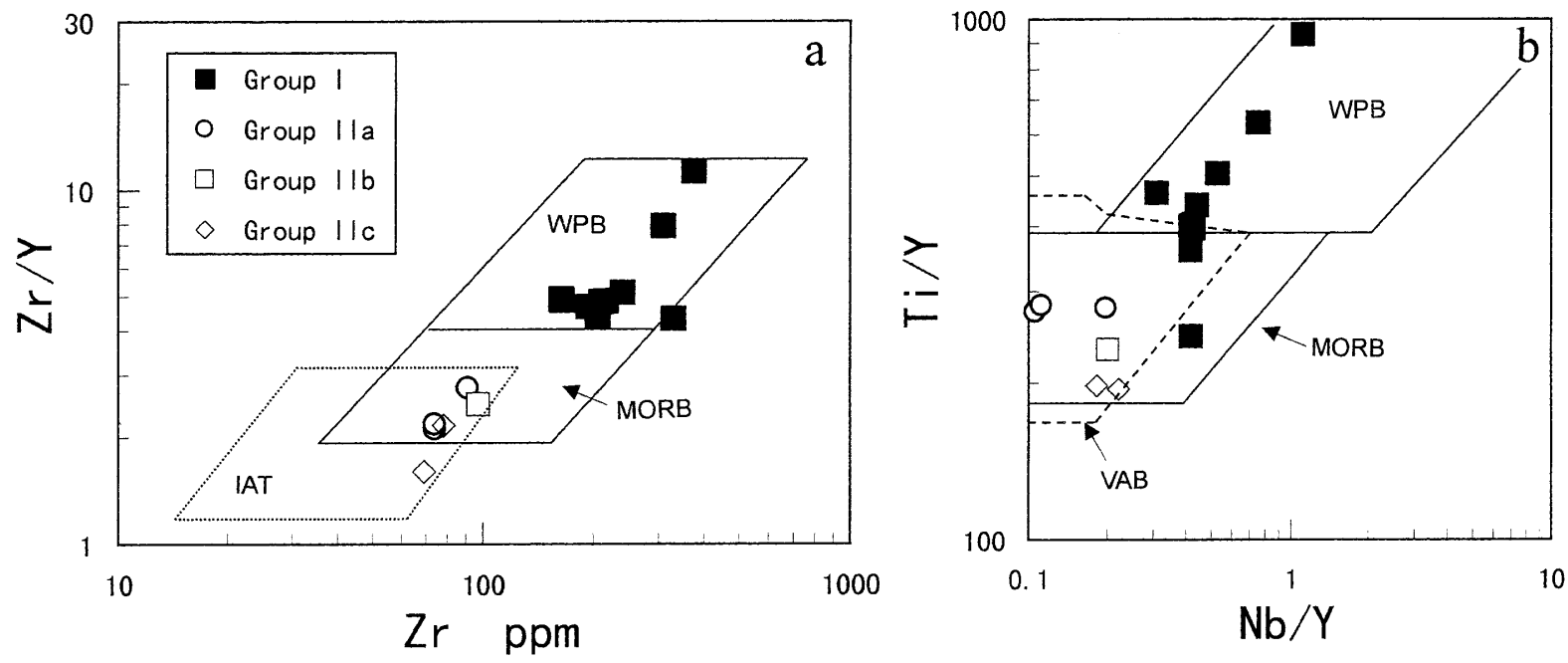

Figure 7. $\mathrm{Zr}-\mathrm{Zr} / \mathrm{Y}$ (a) and $\mathrm{Nb} / \mathrm{Y}-\mathrm{Ti} / \mathrm{Y}$ (b) diagrams for amphibolites in the Oki belt. WPB, within-plate basalt; MORB, mid-oceanic ridge basalt; IAT, island arc tholeiite; VAB, volcanic arc basalt. Diagrams are from Pearce (1983) and Pearce (1982).

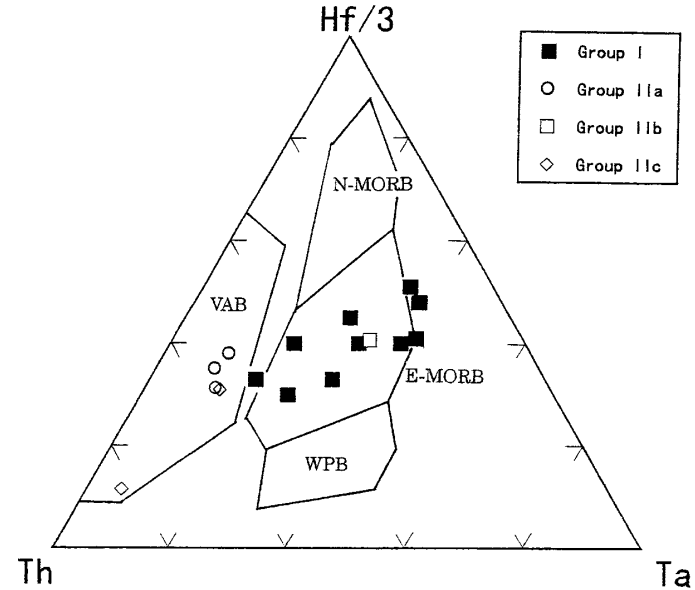

Figure 8. Th-Hf/3-Ta diagram (Wood, 1980) for amphibolites in the Oki belt. N-MORB, N-type MORB; E-MORB, E-type MORB; WPB, within-plate basalt; $\mathrm{VAB}$, volcanic arc basalt.

elements of Group IIb (Figs. 5 and 6) seem to be consistent with the E-MORB for the protolith of Group IIb. Group I amphibolites data are scattered around $\mathrm{E}^{-}$ MORB field rather than within-plate basalt one.

Tectonic discrimination of Group II amphibolites is further supported by the $\mathrm{Ta} / \mathrm{Yb}-\mathrm{Th} / \mathrm{Yb}$ diagram of Pearce (1983) (Fig. 9). Group IIa and IIc amphibolite data are concentrated in the calc-alkaline field, whereas the data of Group IIb plot within a well-defined array including MORB and within-plate basalt (WPB) (Fig. 9). Group I data scatter in more higher $\mathrm{Ta} / \mathrm{Yb}$ and $\mathrm{Th} / \mathrm{Yb}$ space than Group IIb data. $\mathrm{Nb} / \mathrm{Th}$ and $\mathrm{La} /$ $\mathrm{Nb}$ ratios are sometimes used for evaluating the influence of subduction-related components (and crustal

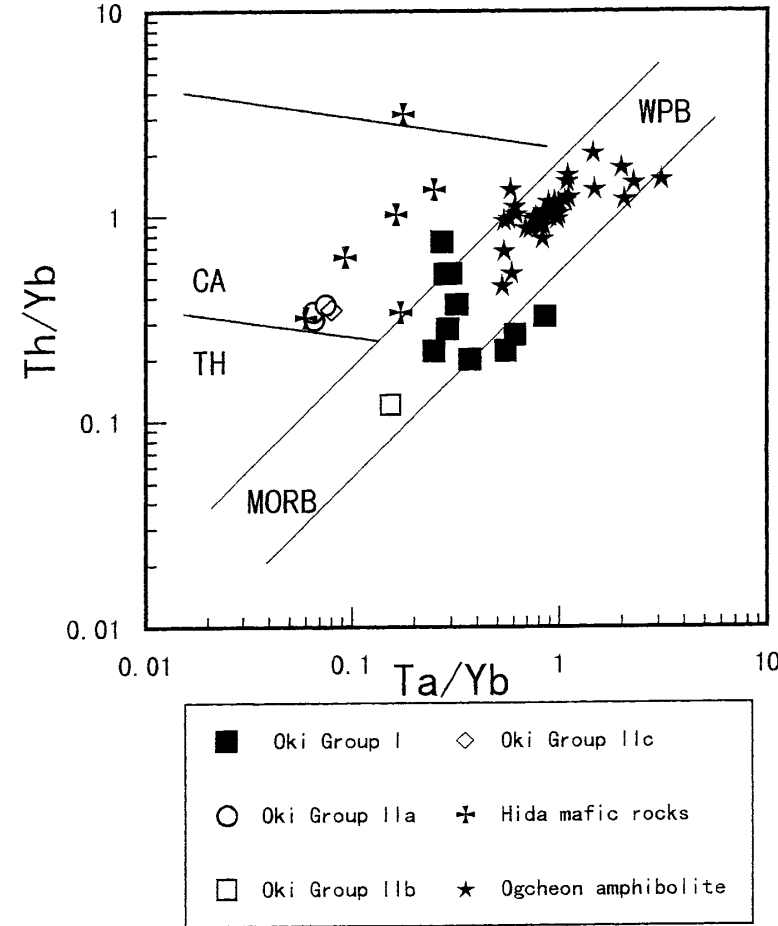

Figure 9. $\mathrm{Ta} / \mathrm{Yb}-\mathrm{Th} / \mathrm{Yb}$ diagram (Pearce, 1983) for amphibolites and mafic igneous rocks of the Oki and Hida belts, and Ogcheon belt (Korea). Data of the mafic igneous rocks of the Hida belt are from Arakawa and Shinmura (1995), and those of the Ogcheon amphibolites are from Lee and Chang (1997).

contamination) (Weaver et al., 1986; Sun and McDonough, 1989). One Group IIb sample (OK06) has $\mathrm{Nb} / \mathrm{Th}$ ratio of 16.3 and $\mathrm{La} / \mathrm{Nb}$ ratio of 0.7 (not shown in the figure), which are very close to the values of the E-MORB. These data are clearly distinguished 
from those of the Group IIa and IIc (2.2-5.3 for Nb/Th and 1.1-2.2 for $\mathrm{La} / \mathrm{Nb}$ ) which have chemical affinity with arc volcanic rocks.

\section{Mixed occurrence of amphibolites with different geo- chemical affinity}

In summary, the analytical data newly identify three protolith types for the amphibolites (within-plate basalt, oceanic island arc basalt and E-type MORB) in the Oki metamorphic rocks. These rocks occur as layer (or sill) or boulder within the paragneiss layers. Mixed occurrence of mafic igneous rocks (or metamorphosed mafic igneous rocks) with different origins and tectonic settings are generally found even in a limited region of Precambrian high-grade metamorphic terranes (e.g., Jahn et al., 1987; Sun et al., 1992). This is probably caused by the complex geological and tectonic history of the regions, including the time and spatial changes of tectonic setting, accretion and amalgamation, later tectonic reconstruction, and so on.

The boulder like occurrence for Group IIa and IIb amphibolites (Fig. 3) may suggest that they were derived independently from the provenance regions and mixed in the gneiss protoliths (pelitic and psammitic rocks). No clear petrographical and textural differences are found between IIa and IIb. Among the analyzed amphibolites, the four amphibolite layers (locations in A, $\mathrm{B}, \mathrm{C}$ and F) belong to Group I. One amphibolite layer ( $2 \mathrm{~m}$ in thickness in location $\mathrm{E}$ ) with island arc chemical affinity belongs to the Group IIc.

Sedimentation ages of original clastic rocks were defined to be Carboniferous to Permian (350-250 Ma) based on the CHIME age data of monazites in the peltic and psammitic gneisses (Suzuki and Adachi, 1994). Employing this chronological constraint, the ages of basaltic magmatism that formed amphibolite protoliths, most of which, are likewise limited in the same time interval. Only from the present data and available geological evidence, we can not fully resolve the genetic relationship of different amphibolite groups and their mixed occurrence in a limited region (Fig. 2). Nevertheless, it is notable that the dominant parts of the amphibolites in the Oki metamorphic rocks yield chemical affinity probably of continental within plate basalt. Preliminary $\mathrm{Sr}-\mathrm{Nd}$ isotope results for the amphibolites show that Group I and Group IIc amphibolites have extremely high initial ${ }^{87} \mathrm{Sr} /{ }^{86} \mathrm{Sr}(0.715-0.732)$ and low $\varepsilon \mathrm{Nd}(-9$ to -17$)$ values assuming a protolith age of 300 Ma. Two component mixing calculation between the primitive basaltic magma and crustal component requires more than $50 \%$ of crustal component for ex- plaining the isotope data (Arakawa et al., 2000a). This is not consistent with major and trace element characteristics. Therefore the crustal contamination during the ascent of original magma is not important process for the magma genesis. The isotope data of the amphibolites are strongly suggestive of their origin from enriched mantle source which was already modified by ancient subducted continental crust (Arakawa et al., 2000a).

\section{Regional correlation and tectonic implication of the Oki metamorphic complex}

Metamorphic rocks of the Oki-Dogo Island have long been regarded as a western continuation of the Hida belt, both having formed at the continental margin (e.g., Miyashiro, 1961). Recent studies have attempted the evaluation of tectonic situation or the other geological correlation of the Oki belt based on the lithological similarity or chronological data. According to the lithofacies Isozaki (1997) demonstrated that the Oki and the Hida belts might have formed in distinct continental margins: Yangtze craton and the Sino-Korean craton, respectively. Evidently the chemical and isotopic signatures of the mafic igneous rocks in the Hida belt indicate that the Hida belt was formed in the continental margin or continental island arc tectonic environment, probably situated to the eastern margin of the North China Block (Sino-Korean craton) or more northward region (Arakawa and Shinmura, 1995; Arakawa et al., 2000b). However, there is no strong evidence for the direct correlation of the Oki belt to the Yangtze craton. Based on the CHIME age determination, Suzuki and Adachi (1991 and 1994) proposed different profilings of age population for detrital zircons and monazite cores in the paragneisses between the Oki and Hida belts. The detrital zircon ages are scattered around $350-3000 \mathrm{Ma}$ in the Oki and 300-2000 Ma in the Hida belt, reflecting the difference in provenance between the two belts (Suzuki and Adachi, 1994). On the other hand, more recently Kunugiza et al. (2000) reported rounded zircon core ages of 1000 to more than $3000 \mathrm{Ma}$ from the Hida belt. This result suggests that there is no significant difference in zircon ages between the two belts. Dallmeyer and Takasu (1998) clarified the difference in cooling and exhumation history between the Oki and Hida belts, though the peak metamorphic events might have occurred at the same time (ca. $250 \mathrm{Ma}$ ) in both belts (Suzuki and Adachi, 1994).

According to the paleomagnetic reconstruction of the location of SW Japan before Miocene opening of Japan Sea (Otofuji and Matsuda, 1984), the Oki belt 


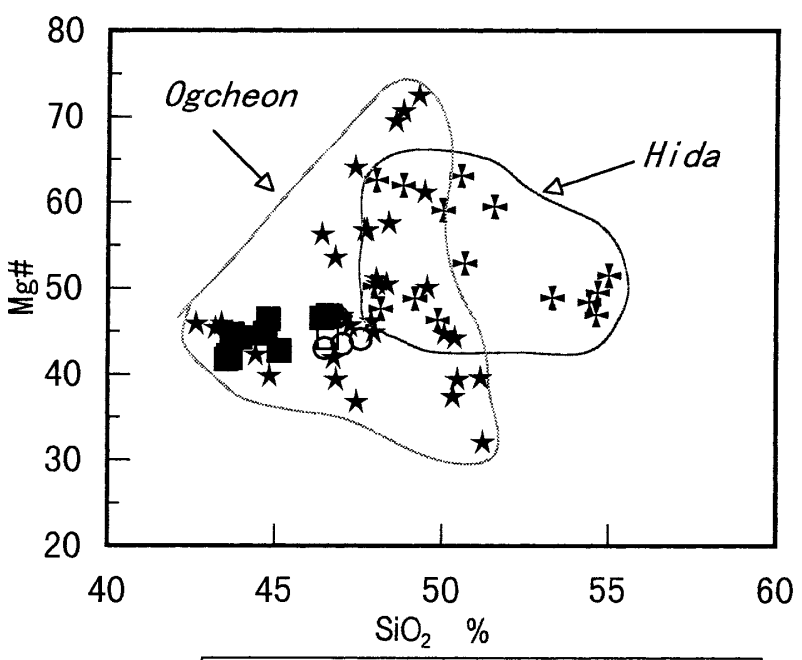

$\square$ Oki Group I $\diamond$ Oki Group Ilc
0 Oki Group IIa + Hida mafic rocks
$\square$ Oki Group Ilb $\star$ Ogcheon amphibolite

Figure 10. Comparison of $\mathrm{SiO}_{2}$ (wt\%) and $\mathrm{Mg}$ value $(\mathrm{Mg} \#)$ of amphibolites and mafic igneous rocks in the Oki and Hida belts, and Ogcheon belt (Korea). Data sources of the Hida and Ogcheon belts are the same in Figure 9.

appears to be located in the northeastern continuation of the Ogcheon belt, Korea. Figure 9 represents a comparison of trace element compositions of mafic igneous rocks between the Hida, Oki and Ogcheon belts. Although amphibolites with oceanic arc and MORB signatures are involved in the Oki belt, the dominance of Group I amphibolites may imply that the Oki belt possibly formed within the continental plate, but not in the continental margin with subduction zone as assumed for the Hida belt (central Japan) (Fig. 9). Amphibolites (latest Proterozoic to Paleozoic in age) in the Ogcheon belt, Korea, show tholeiitic affinity that developed in the within-plate tectonic environment (Cluzel, 1992; Lee and Chang, 1997; Lee et al., 1998). Their close association with the concurrent felsic metavolcanic rocks led to the model that the Ogcheon belt formed in intracontinental rift zone (Cluzel, 1992). Felsic metavolcanic rocks are lacking in the Oki belt. Major and trace element data of the amphibolites posses some similarities between the Oki and the Ogcheon belts. In $\mathrm{Mg} \#-\mathrm{SiO}_{2}$ diagram (Fig. 10), the amphibolite of the Oki belt are within the field of the Ogcheon amphibolites, but differ clearly from those of the mafic rocks in the Hida belt. The tectonic setting deduced from the chemical compositions resembles the Oki and Ogcheon belts. Although the disagreements in protolith age and $\mathrm{Sr}-\mathrm{Nd}$ isotope data for the am- phibolites in the Oki and Ogcheon belts (Lee and Chang, 1997; Arakawa et al., 2000a) make the direct correlation of the two belts still problematic, there may be a possibility that the two belts formed and evolved in the different parts of the same tectonic unit or the same continent.

\section{Concluding remarks}

The geochemical studies revealed different types of amphibolites in the Oki metamorphic complex, in OkiDogo Island (Japan). Amphibolites show tholeiitic to alkaline chemical affinity, and are classified into two groups (Group I and II). Group I amphibolites, all having layered or sill-like occurrence, are characterized by low $\mathrm{SiO}_{2}$ (43.5-46.6\%) and high $\mathrm{TiO}_{2}(>2.6 \%)$ and $\mathrm{P}_{2} \mathrm{O}_{5}(>0.5 \%)$, whereas Group II amphibolites by high $\mathrm{SiO}_{2}(46.5-47.6 \%)$ and low $\mathrm{TiO}_{2}(<1.6 \%)$ and $\mathrm{P}_{2} \mathrm{O}_{5}(<$ $0.2 \%)$. Group I amphibolites present relatively high incompatible element contents and their high ratios $(\mathrm{Zr} /$ $\mathrm{Y}, \mathrm{Ti} / \mathrm{Y}$ and $\mathrm{Ta} / \mathrm{Yb}$ etc.), and LREE enriched patterns, and are placed in the category of the within-plate basalt (WPB). On the contrary, Group II amphibolites yield low incompatible element contents and ratios, and nearly flat REE patterns. Group II amphibolites are further classified into three sub-groups: IIa, IIb and IIc. Both Group IIa and IIb are included as different boulders within a psammitic gneiss at the same outcrop, and Group IIc is a layered amphibolite. Trace element data suggest that the protoliths of Group IIa and IIc amphibolites correlate with tholeiitic basalt within oceanic island arc tectonic setting. One Group IIb amphibolite possesses chemical affinity with E-type MORB. Excluding the boulder-like Group IIa and IIb amphibolites which might not have formed in situ, the dominant occurrence of Group I amphibolites with within-plate basalt signatures allows the interpretation that the protolith formation of amphibolites in the Oki belt occurred within a continental tectonic environment.

\section{Acknowledgements}

We would like to thank to $\mathrm{K}$. Hisada for providing us some amphibolite samples in Oki-Dogo Island. The careful and constructive reviews by T. Kano and K.C. $\mathrm{Na}$, and an anonymous referee improved the manuscript. This work was partly supported by a Grant-in Aid from the Ministry of Education, Science and Culture, Japan.

\section{References}

Arakawa, Y., and Shinmura, T. (1995) Nd-Sr isotopic and 
geochemical characteristics of two contrasting types of calc-alkaline plutons in the Hida belt, Japan. Chemical Geology, 124, 217-232.

Arakawa, Y., Kouta, T. and Amakawa, H. (2000a) Sr and $\mathrm{Nd}$ isotope compositions of amphibolites, and psammitic and pelitic gneisses in Oki-Dogo Island, Japan. Abstract of $107^{\text {th }}$ Annual Meeting of the Geological Society of Japan, 165 (in Japanese).

Arakawa, Y., Saito, Y. and Amakawa, H. (2000b) Crustal development of the Hida belt, Japan: Evidence from $\mathrm{Nd}^{-}$ $\mathrm{Sr}$ isotopic and chemical characteristics of igneous rocks and metamorphic rocks. Tectonophysics, 328, 183-204.

Asaki, T. and Yoshida, T. (1998) Subduction-zone type greenstones from the northern Shimanto belt in southeastern Tokushima Prefecture, Southwest Japan. Journal of Mineralogy, Petrology and Economic Geology, 93, 83-102 (in Japanese with English abstract).

Cluzel, D. (1992) Ordovician bimodal magmatism in the Ogcheon belt (South Korea): intracontinental rift-related volcanic activity. Journal of Southeast. Asian Earth Sciences, 7, 195-209.

Cox, K.G. and Hawkesworth, C.J. (1985) Geochemical stratigraphy of the Decan Traps, at Mahabaleshwar, western Ghats, India, with implications for open system magmatic processes. Journal of Petrology, 26, 355-377.

Dallmeyer, R.D. and Takasu, A. (1998) ${ }^{40} \mathrm{Ar} /{ }^{39} \mathrm{Ar}$ mineral ages from the Oki metamorphic complex, Oki-Dogo, southwest Japan: implications for regional correlations. Journal of Asian Earth Sciences, 16, 437-448.

Engel, A.E.J. and Engel, C.G. (1962) Hornblendes formed during progressive metamorphism of amphibolites, northwest Adirondack Mountains, New York. Geological Society of America Bulletin, 73, 1499-1514.

Hayase, I. And Ishizaka, K. (1967) Rb-Sr dating on the rocks in Japan (I), southwest Japan. Journal of Japanese Association of Mineralogists, Petrologists and Economic Geologists, 58, 201-212 (in Japanese with English abstract).

Hoshino, M. (1979a) Two pyroxene amphibolite in Dogo, Oki Islands, Shimane-ken, Japan. Journal of Japanese Association of Mineralogists, Petrologists and Economic Geologists, 74, 87-99.

Hoshino, M. (1979b) Corundum-bearing pelitic gneiss from Dogo, Oki Islands. In The Basement of the Japanese Islands-Prof. Hiroshi Kano Memorial Volume, 85-88.

Isozaki, Y., (1997) Contrasting two types of orogen in Permo-Triassic Japan: Accretionary versus collisional. The Island Arc, 6, 2-24.

Jahn, B.M., Auvray, B., Cornichet, J., Bai, Y.L., Shen, Q.H. and Liu, D.Y. (1987) $3.5 \mathrm{Ga}$ old amphibolites from eastern Hebei Province, China: Field occurrence, petrography, Sm $-\mathrm{Nd}$ isochron age and REE geochemistry. Precambrian Research, 34, 311-346.

Jahn, B.M., Cornichet, Cong, B.L. and Yui, T.F. (1996) Ultrahigh $-\varepsilon \mathrm{Nd}$ eclogites from an ultrahigh pressure metamorphic terrane of China. Chemical Geology, 127, 61-79.

Jahn, B.M., Wu, F., Lo, C.H. and Tsai, C.H. (1999) Crustmantle interaction induced by deep subduction of the continental crust: geochemical and $\mathrm{Sr}-\mathrm{Nd}$ isotopic evidence from post-collisional mafic-ultramafic intrusions of the northern Dabie complex, central China. Chemical
Geology, 157, 119-146.

Kunugiza, K., Goto, A., Tsutsumi, Y., Sano, Y., Yokoyama, K. and Sohma, T. (2000) Ages of the Funatsu granitoids in the Hida belt. Abst. of 1999 annual meeting of the Japanese Association of Mineralogists, Petrologists and Economic geologists (in Japanese), 62.

Lee, K.S., Chang, H.W. and Park, K.H. (1998) Neoproterozoic bimodal volcanism in the central Ogcheon belt, Korea: age and tectonic implication. Precambrian Research, 89, 47-57.

Lee, S.R. and Chang, K.H. (1997) Geochemistry and Sr-Nd$\mathrm{Pb}$ isotopic systematics of the Ogcheon amphibolites from the central Ogcheon belt, Korea: Implication for the source heterogeneity. Geochemical Journal, 31, 223-243.

Miyashiro, A. (1961) Evolution of metamorphic belts. Journal of Petrology, 2, 277-311.

Nakamura, N. (1974) Determination of REE, Ba, Fe, Mg, Na and $\mathrm{K}$ in carbonaceous and ordinary chondrites. Geochim. Cosmochim. Acta, 38, 757-775.

Ohta, M. (1963) Oki metamorphism. Journal of Japanese Association of Mineralogists, Petrologists and Economic Geologists, 49, 189-205 (in Japanese with English abstract).

Otofuji, Y. and Matsuda, T. (1984) Timing of rotational motion of Southwest Japan inferred from paleomagnetism. Earth and Planetary Science Letter, 70, 373-382.

Pearce, J.A. (1982) Trace element characteristics of lavas from destructive plate bounders. In Andesites: orogenic andesites and related rocks (Thorpe, R.S. Ed.). Chichester: Wiley, 525-548.

Pearce, J.A. (1983) The role of sub-continental lithosphere in magma genesis at destructive plate margins. In Continental basalts and mantle xenoliths (Hawkesworth, C.J. and Norry, M.J. Eds.). Nantwich: Shiva, 230-249.

Saunders, A.D. and Tarney, J. (1979) The geochemistry of basalts from a back-arc spreading center in the East Scotia Sea. Geochimica Cosmochimica Acta, 43, 555-572.

Shibata K. and Nozawa, T. (1966) K-Ar ages of the Hida metamorphic rocks, Amo-Tsunokawa area and Oki area, Japan. Bulletin of Geological Survey of Japan, 17, 410435.

Sun, M., Armstrong, R.L. and Lambert, R.S.J. (1992) Petrochemistry and $\mathrm{Sr}, \mathrm{Pb}$ and $\mathrm{Nd}$ isotopic geochemistry of early Precambrian rocks, Wutaishan and Taihangshan areas, China. Precambrian Research, 56, 1-31.

Sun, S.S. and McDonough, W.E. (1989) Chemical and isotopic systematics of oceanic basalts: implications for mantle composition and processes. In Magmatism in the Ocean Basins (Saunders, A.D. and Norry, M.J. Eds.). Geological Society, Special Publication, 42, 313-345.

Suzuki, K. and Adachi, M. (1991) The chemical Th-U-total $\mathrm{Pb}$ isochron ages of zircon and monazite from the Gray granite of the Hida terrane, Japan. Journal of Earth Science, Nagoya University, 38, 11-38.

Suzuki, K. and Adachi, M. (1994) Middle Precambrian detrital monazite and zircon from the Hida gneiss on OkiDogo Island, Japan: their origin and implications for the correlation of basement gneiss of Southwest Japan and Korea. Tectonophysics, 235, 277-292.

Tainosho, Y., Shibata, K. and Uchiumi, S. (1991) Granitic rocks in Dogo, Oki Islands, Shimane Prefecture, Japan. Journal of Geological Society of Japan, 97, 53-60 (in 
Japanese with English abstract).

Tanaka, T. and Hoshino, M. (1987) Sm-Nd ages of Oki metamorphic rcoks and their geological significance. Abstract of $94^{\text {th }}$ Annual Meeting of Geological Society of Japan, 492 (in Japanese).

Tsunogae, T., Hamada, K., Fujiwara, N. and Anyoji, E. (1995) Metamorphic history of the pelitic migmatites from the Oki-Dogo island. Abstract of 1995 Joint Meeting of Society of Resource Geology, Japanese Association of Mineralogists, Petrologists and Economic Geologists, and Mining Society of Japan, 160 (in Japanese).

Weaver, B.L., Wood, D.A., Tarney, J. and Joron, J.L. (1986) Role of subducted sediment in the genesis of Ocean-island basalts: geochemical evidence from South Atlantic Ocean islands. Geology, 14, 275-278.
Winchester, J.A. and Floyd, P.A. (1977). Geochemical discrimination of different magma series and their differentiation products using immobile elements. Chemical Geology, 20, 325-344.

Wood, D.A., Joron, J.L. and Treuil, M. (1979) A reappraisal of the use of trace elements to classify and discriminate between magma series erupted in different tectonic settings. Earth Planet. Sci. Lett., 45, 326-336.

Yamashita, K. and Yanagi, T. (1994) U-Pb and Rb-Sr dating of the Oki metamorphic rocks, the Oki Island, Southwest Japan. Geochemical Journal, 28, 333-339.

Manuscript received; 19 April, 2001 Manuscript accepted; 23 July, 2001 